\title{
ПРИРОДНО-ЗАПОВІДНИЙ ФОНД У СТРУКТУРІ РЕКРЕАЦЙНОГО ПРИРОДОКОРИСТУВАННЯ КИЇВСЬКОЇ ОБЛАСТІ
}

\author{
Пологовська Ю. Ю., Щабельська В. Г.
}

\section{ВСТУП}

У процесі свого розвитку суспільство поставило під загрозу існування екологічних систем і природних комплексів, які відіграють провідну роль у збереженні природного каркасу Землі, відтворенні життя та біологічного різноманіття. Сучасну екологічну ситуацію в Україні можна охарактеризувати як кризову, тому створення природоохоронних територій $\epsilon$ єдиним із реально працюючих механізмів охорони природних екосистем, ландшафтів, рослинних угруповань і рідкісних видів тварин та однією з умов екологічної безпеки як окремих територій, так і країни загалом ${ }^{1}$. Питання охорони довкілля також варто розглядати як один із пріоритетів України на шляху до євроінтеграції.

Ядром національної єдиної територіальної системи природних територій та об'єктів особливої державної охорони є території та об'єкти природно-заповідного фонду (далі - ПЗФ), які мають особливу природоохоронну, наукову, естетичну, рекреаційну та інші цінності і виділені з метою збереження природної різноманітності ландшафтів, генофонду тваринного і рослинного світу, підтримання загального екологічного балансу та забезпечення фонового моніторингу навколишнього природного середовища ${ }^{2}$. Відповідно до Закону України «Про природно-заповідний фонд України» (№ 2456-XII16 від 16 червня 1992 р.) розрізняють дві групи природно-заповідних територій: природні та колекційно-паркового типу (штучні). До природних територій та об'єктів належать природні заповідники, біосферні заповідники, національні природні парки, регіональні ландшафтні парки, заказники, пам'ятки природи, заповідні урочища, до штучно створених об'єктів ботанічні сади, дендрологічні парки, зоологічні парки, парки-пам'ятки садово-паркового мистецтва ${ }^{3}$.

Для гарантування екологічної стійкості будь-якого регіону необхідно, щоб частка заповідних територій становила не менше $10-15 \%$ його

\footnotetext{
${ }^{1}$ Дуднікова I.І. Концепція заповідної справи: сутність, значення, основні тенденції становлення і формування. URL: http://www.zgia.zp.ua/gazeta/visnik_50_231.pdf

2 Андронов В.А., Варивода Є.О., Тітенко Г.В. Заповідна справа : навч. посібник. Харків : НУЦЗУ, 2013. 204 c.

3 Про природно-заповідний фонд України: Закон України від 16 червня 1992 р. № 2456-XII16. URL: https://zakon.rada.gov.ua/laws/show/2456-12\#Text
} 
загальної площі. У 2019 р. на Київщині рівень заповідності сягнув $12,2 \%$, що $є$ вищим ніж у середньому в Україні $(7,1 \%)$, але меншим ніж у таких областях, як Чернівецька $(13,7 \%)$, Закарпатська $(14,4 \%)$, ІваноФранківська $(15,9 \%)$ та Хмельницька $(15,9 \%)^{4}$.

\section{1. Природно-заповідний фонд Київської області як об'єкт рекреаційного природокористування}

Історія формування сучасного природно-заповідного фонду Київської області охоплює понад два століття. Першими природоохоронними територіями регіону варто вважати дендропарки, які створювалися у великих маєтках поміщиків. Деякі з них збереглись і нині мають статус парків-пам'яток садово-паркового мистецтва («Згурівський», «Кагарлицький», «Копилівський», «Ташанський») або дендропарків («Олександрія»). Історія розвитку мережі ПЗФ Київщини включає як періоди активного створення територій, що охороняються, так і їх знищення. Становлення природоохоронної справи на Київщині розпочалося у 1928 р. зі створення Українського комітету охорони пам'яток природи. На початку 30-х років XX століття за даними реєстру заповідних об'єктів М. Шаліти в області нараховувалось 125 пам'яток природи. Після Другої світової війни частина заповідників була ліквідована, а їх території відведені під будівництво дач, санаторіїв, будинків відпочинку. Окремим із них надавався статус мисливських господарств. У 1949 р. згідно з урядовою постановою «Про охорону природи на території Української РСР» було заплановано створення 11 нових лісових заповідників, серед яких Чорнобильський у Київській області.

Протягом 50-60-х pp. XX століття природно-заповідні об'єкти практично не створювались, але були організовані заповідні мисливські господарства «Заліське» та «Дніпровсько-Тетерівське». Лише після створення у 1967 p. спеціального природоохоронного органу Держкомприроди УРСР заповідна справа в області пожвавилась, в 1968 р. статус заповідних надано 26 об'єктам, а в 1972 р. - 15. У 80-90-х pp. минулого століття кількість заповідних об’єктів збільшилась порівняно 3 70-ми рр. ${ }^{5}$ (рис. 1 ).

За роки незалежності в Україні прийнято закони України «Про природно-заповідний фонд України» (№ 2456-XII від 16 червня 1992 р.), «Про Загальнодержавну програму формування національної екологічної мережі України на 2000-2015 роки» (№ 1989 від 21 вересня 2000 р.), «Про екологічну мережу України» (№ 1864-IV від 24 червня 2004 р.), затверджені та впроваджуються загальнодержавні програми перспективного розвитку заповідної справи в Україні «Заповідники»,

\footnotetext{
${ }^{4}$ Касперевич Л.В. Аналіз стану природно-заповідного фонду України та Львівської області. URL: http://www.investplan.com.ua/pdf/9_2017/17.pdf

5, Природно-заповідний фонд Київської області / Василюк О. та ін. Київ : НЕЦУ, 2012. 338 с. 
регіональна програма розвитку природно-заповідного фонду Київської області «Київщина заповідна» на 2017-2020 рр. Зазначимо, що 3 2000-х рр. організаційні заходи спрямовані на створення та розвиток на Київщині нових національних природних парків «Переяславський», «Подесіння», «Дніпровсько-Тетерівський» та ландшафтного заказника загальнодержавного значення «Конча-Озерна» ${ }^{6}$.

У 2016 р. було створено Чорнобильський радіаційно-екологічний біосферний заповідник площею 226,96 тис. га 3 метою збереження в природному стані найбільш типових природних комплексів Полісся, забезпечення підтримки та підвищення бар'єрної функції Чорнобильської зони відчуження та зони безумовного (обов'язкового) відселення, стабілізації гідрологічного режиму та реабілітації територій, забруднених радіонуклідами, сприяння організації та проведенню міжнародних наукових досліджень .

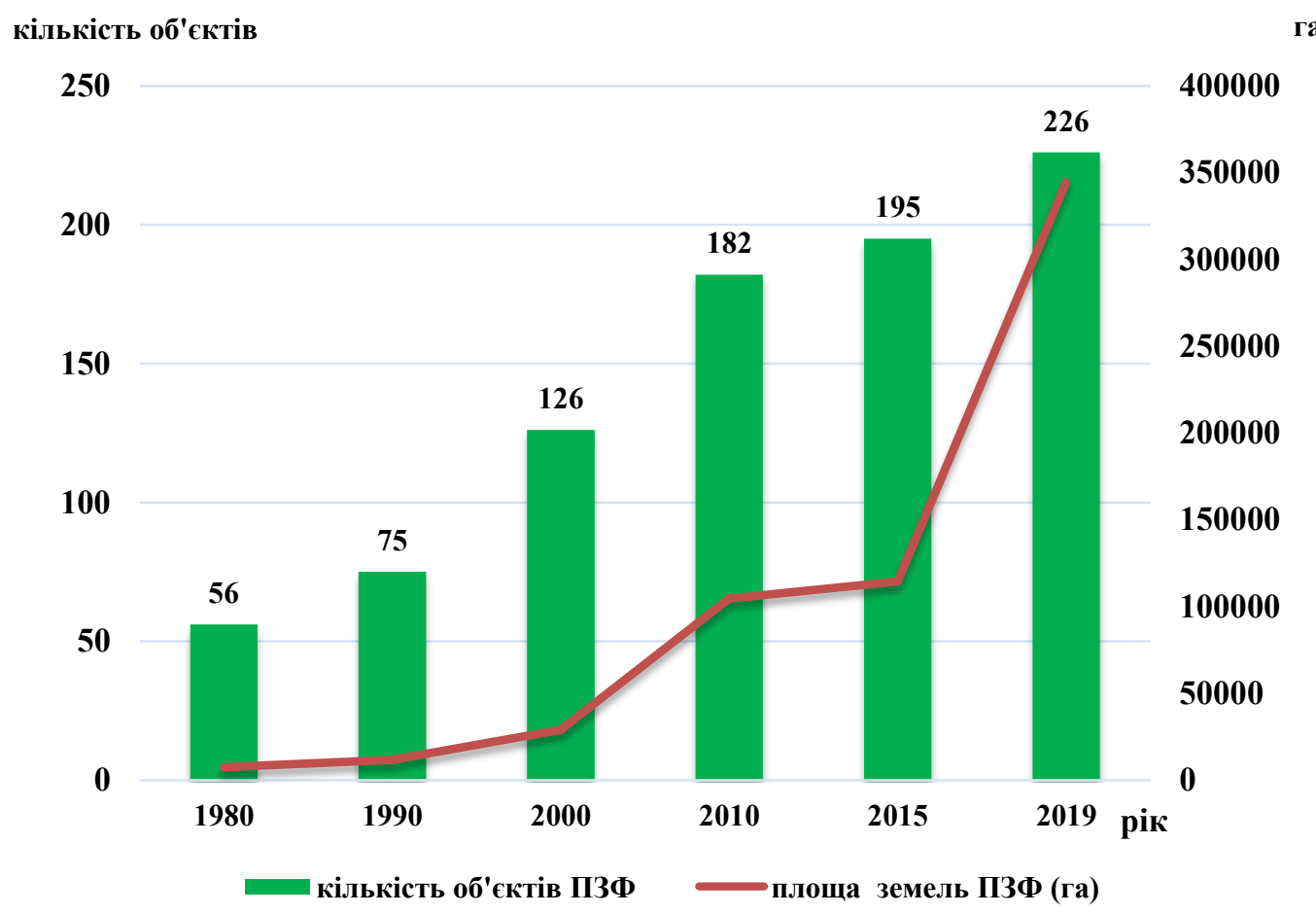

Рис. 1. Динаміка розвитку територій та об'сктів природно-заповідного фонду Київської області

\footnotetext{
${ }^{6}$ Про розширення мережі та територій національних природних парків та інших природнозаповідних об’єктів : Указ Президента України від від 1 грудня 2008 р. № 1129/2008. URL: https://zakon.rada.gov.ua/laws/show/1129/2008\#Text

7 Про створення Чорнобильського радіаційно-екологічного біосферного заповідника : Указ Президента України від 26 квітня 2016 р. № 174/2016 p. URL: https://zakon.rada.gov.ua/laws/ show/174/2016\#Text
} 
Згідно з даними департаменту екології та природних ресурсів Київської обласної державної адміністрації ПЗФ області станом на 01.01.2019 p. нараховує 226 природних комплексів і об'єктів, які займають площу 344,46 тис. га, 3 них 25 об'єктів загальнодержавного значення і 201 об’єкт місцевого значення загальною площею 308,74 тис. га та 35,72 тис. га відповідно 8 (табл. 1).

До складу природно-заповідного фонду області входить 1 біосферний заповідник («Чорнобильський радіаційно-екологічний»), 2 національних природних парки («Залісся» та «Білоозерський»), 4 регіональних ландшафтних парки («Трахтемирів», «Богуславль», «Пташиний рай», «Яготинський імені Гетьмана Кирила Розумовського»), 105 заказників, 82 пам'ятки природи, 17 заповідних урочищ, 1 дендрологічний парк, 14 парків-пам'яток садово-паркового мистецтва' .

\section{Таблиця 1}

\section{Розподіл територій та об'сктів природно-заповідного фонду (ПЗФ)} Київської області за їх значенням, категоріями та типами (станом на 01.01.2019 р.) ${ }^{10}$

\begin{tabular}{|c|c|c|c|c|c|c|c|}
\hline \multirow{3}{*}{$\begin{array}{c}\text { Категорії об'сктів } \\
\text { ПЗФ }\end{array}$} & \multicolumn{6}{|c|}{ Об’скти ПЗФ } & \multirow{3}{*}{$\begin{array}{l}0 \\
\\
0 \\
0\end{array}$} \\
\hline & \multicolumn{2}{|c|}{$\begin{array}{c}\text { Загально- } \\
\text { державного } \\
\text { значення } \\
\end{array}$} & \multicolumn{2}{|c|}{ Місцевого значення } & \multicolumn{2}{|r|}{ Разом } & \\
\hline & $\begin{array}{l}\text { кіль- } \\
\text { кість }\end{array}$ & $\begin{array}{l}\text { плоша, } \\
\text { га }\end{array}$ & $\begin{array}{l}\text { кіль- } \\
\text { кість }\end{array}$ & площа, га & $\begin{array}{l}\text { кіль- } \\
\text { кість }\end{array}$ & площа, га & \\
\hline 1 & 2 & 3 & 4 & 5 & 6 & 7 & 8 \\
\hline $\begin{array}{l}\text { Природні } \\
\text { заповідники }\end{array}$ & - & - & - & - & - & - & - \\
\hline $\begin{array}{l}\text { Біосферні } \\
\text { заповідники }\end{array}$ & 1 & 226964,7 & & & 1 & 226964,7 & 65,9 \\
\hline $\begin{array}{l}\text { Національні } \\
\text { природні парки }\end{array}$ & 2 & 17206,72 & & & 2 & 17206,72 & 5,0 \\
\hline $\begin{array}{l}\text { Регіональні } \\
\text { ландшафтні парки }\end{array}$ & & & 4 & 5754,5673 & 4 & 5754,5673 & 1,7 \\
\hline Заказники, загалом & 16 & 63584,3 & 89 & 27842,5352 & 105 & 91426,8352 & 26,5 \\
\hline $\begin{array}{l}\text { у тому числі: } \\
\text { ландшафтні }\end{array}$ & 6 & 5612,0 & 34 & 19683,6132 & 40 & 25295,6132 & \\
\hline лісові & 3 & 2296,5 & 13 & 1880,892 & 16 & 4177,392 & \\
\hline ботанічні & - & - & 22 & 1760,03 & 22 & 1760,03 & \\
\hline загальнозоологічні & 1 & 48870,0 & 1 & 212,0 & 2 & 49082,0 & \\
\hline орнітологічні & 2 & 489,7 & 6 & 506,1 & 8 & 995,8 & \\
\hline іхтіологічні & - & - & 2 & 605,0 & 2 & 605,0 & \\
\hline гідрологічні & 4 & 6316,1 & 11 & 3194,9 & 15 & 9511,0 & \\
\hline
\end{tabular}

${ }^{8}$ Екологічний паспорт Київської області. 2018 p. URL: https://menr.gov.ua/news/33529.html

${ }^{9}$ Екологічний паспорт Київської області. 2018 p. URL: https://menr.gov.ua/news/33529.html

${ }^{10}$ Екологічний паспорт Київської області. 2018 p. URL: https://menr.gov.ua/news/33529.html 
Закінчення табл. 1

\begin{tabular}{|l|c|c|c|c|c|c|c|}
\hline \multicolumn{1}{|c|}{1} & 2 & 3 & 4 & 5 & 6 & 7 & 8 \\
\hline $\begin{array}{l}\text { Пам'ятки природи, } \\
\text { загалом }\end{array}$ & 2 & 92,0 & 80 & 366,065 & $\mathbf{8 2}$ & 458,065 & 0,13 \\
\hline $\begin{array}{l}\text { у тому числі: } \\
\text { комплексні }\end{array}$ & - & - & 6 & 14,9 & 6 & 14,9 & \\
\hline ботанічні & 2 & 92,0 & 65 & 143,69 & 67 & 235,69 & \\
\hline зоологічні & - & - & - & - & - & - & \\
\hline гідрологічні & - & - & 4 & 181,725 & 4 & 181,725 & \\
\hline геологічні & - & - & 5 & 25,75 & 5 & 25,75 & 0,46 \\
\hline Заповідні урочища & - & - & 17 & 1571,7 & $\mathbf{1 7}$ & 1571,7 & - \\
\hline Ботанічні сади & - & - & - & - & - & - & 0,12 \\
\hline $\begin{array}{l}\text { Дендрологічні } \\
\text { парки }\end{array}$ & 1 & 405,8 & - & - & $\mathbf{1}$ & 405,8 & 0,19 \\
\hline $\begin{array}{l}\text { Парки-пам'ятки } \\
\text { садово-паркового } \\
\text { мистецтва }\end{array}$ & 3 & 488,5 & 11 & 185,8747 & $\mathbf{1 4}$ & 674,3747 & - \\
\hline Зоологічні парки & - & - & - & - & - & - & $\mathbf{1 0 0}$ \\
\hline 3АГАЛОМ & $\mathbf{2 5}$ & $\mathbf{3 0 8 7 4 2 , 0 2}$ & $\mathbf{2 0 1}$ & $\mathbf{3 5 7 2 0 , 7 4 2 2}$ & $\mathbf{2 2 6}$ & $\mathbf{3 4 4 4 6 2 , 7 6 2 2}$ & \\
\hline
\end{tabular}

Особливістю природно-заповідного фонду області є те, що 46,5\% його об'єктів - це заказники різного типу. Серед них на ландшафтні припадає $38,1 \%$, ботанічні - 21,0\%, лісові - 15,3\%. Пам'ятки природи становлять $36,3 \%$ від загальної кількості об'єктів ПЗФ області, а дві 3 них загальнодержавного значення (ботанічні пам'ятки природи «Урочище Бабка» і «Круглик»). Загалом у Київській області нараховується вісім категорій природних територій та об’єктів ПЗФ, що, за оцінками вчених, вважається достатнім. Досить велика варіація природних об'єктів свідчить про мозаїчну структуру природно-заповідного фонду регіону, що сприяє збереженню біо- й ландшафтного різноманіття ${ }^{11}$.

Показник щільності об'єктів дослідження становить 0,80 об'єктів на $100 \mathrm{kм}^{2}$. Коефіцієнт інсуляризованості сягає позначки 0,4, що свідчить про наявність значної кількості природно-заповідних об'єктів площею менше 50 га (134 об’єкти ПЗФ), які є екологічно нестабільними та не виконують повною мірою свої функції. Найбільш сприятлива ситуація склалася на території Згурівського, Таращанського, Броварського, Миронівського районів та в зоні відчуження і безумовного (обов'язкового) відселення Іванківського та Поліського районів, де цей показник коливається в межах від 0 до 0,1 .

Територія Київської області характеризується нерівномірним розподілом об'єктів ПЗФ як у кількісному, так і якісному співвідношенні. Якщо заказники та пам'ятки природи розподілені рівномірно й представлені майже у кожному районі, то заповідні урочища і парки-

\footnotetext{
11 Землі природно-заповідного фонду Київської області: сучасний стан, проблеми, перспективи. URL: http://journals.nubip.edu.ua/index.php/Zemleustriy/article/viewFile/ 6539/6411
} 
пам'ятки садово-паркового мистецтва - у 12 районах. Один із п'яти біосферних заповідників України «Чорнобильський радіаційноекологічний» розташований на території Іванківського та Поліського районів у зоні відчуження та безумовного (обов'язкового) відселення, 2 НПП «Залісся» і «Білоозерський» у Броварському та ПереяславХмельницькому районах відповідно. Регіональні ландшафтні парки розміщені в Богуславському («Богуславль»), Вишгородському («Пташиний рай»), Миронівському («Трахтемирів»), Яготинському («Яготинський імені Гетьмана Кирила Розумовського») районах, дендропарк «Олександрія» - в Білоцерківському ${ }^{12}$.

Найбільша кількість різнорангових об'єктів знаходиться у Вишгородському (23 об’єкти ПЗФ), Києво-Святошинському, ПереяславХмельницькому та Обухівському районах (по 19 об'єктів). Найменша кількість об'єктів ПЗФ сконцентрована в Поліському (1), Рокитнянському (2), Таращанському (3), Ставищенському (4) районах ${ }^{13}$. Таким чином, рівномірність розподілу об'єктів ПЗФ за 3-бальною шкалою можна оцінити в 1 бал. Це свідчить про відсутність науково обгрунтованого підходу до формування ПЗФ на Київщині. Тому нині мережа об'єктів ПЗФ охоплює територіально ізольовані об'єкти, які виконують переважно функцію пасивного збереження біотопів.

У структурі ПЗФ Київської області найбільшу площу, крім біосферного заповідника «Чорнобильський радіаційно-екологічний» (65,9\% від загальної площі ПЗФ області), займають заказники - 26,5\% (серед яких найбільші «Чорнобильський спеціальний» - 48,87 тис. га, «Бориспільські острови» - 6,9 тис. га), національні природні парки - 5\%, («Залісся» - 13,54 тис. га, «Білоозерський» - 3,65 тис. га), а також регіональний ландшафтний парк «Трахтемирів» $(5,14$ тис. га).

Найбільші площі природно-заповідних комплексів концентруються в зоні відчуження та безумовного (обов'язкового) відселення, Броварському, Бориспільському, Вишгородсьому, Миронівському районах, а найменші - в Рокитнянському, Ставищенському, Баришівському, Таращанському, Сквирському ${ }^{14}$ (рис. 2).

Найбільший відсоток заповідності територій у зоні відчуження та безумовного (обов'язкового) відселення Іванківського та Поліського районів (67\%), Броварському районі $(14,7 \%)$, а найменший - в Рокитнянському $(0,25 \%)$, Сквирському $(0,38 \%)$, Баришівському $(0,43 \%)$, Таращанському $(0,48 \%)$ районах, які характеризуються найвищим ступенем антропогенного перетворення ландшафтів. У решті районів він коливається від 1 до 4,7\%.

${ }^{12}$ Екологічний паспорт Київської області. 2018 p. URL: https://menr.gov.ua/news/33529.html
${ }^{13}$ Екологічний паспорт Київської області. 2018 p. URL: https://menr.gov.ua/news/33529.html
${ }^{14}$ Екологічний паспорт Київської області. 2018 p. URL: https://menr.gov.ua/news/33529.html 
В області спостерігається певна відповідність показників рівня заповідності територій та коефіцієнта інсуляризованості: позитивна - в зоні відчуження та безумовного (обов'язкового) відселення, в Броварському (низькі показники коефіцієнту інсуляризованості - 0,14 та 0,1 відповідно при високому рівні заповідності - 67\% та 14,7\%), Миронівському i Бориспільському районах (відповідно, низькі показники коефіцієнта інсуляризованості - 0,20 та 0,25 та середні показники рівня заповідності - 6,8\% і 6\%); негативна - у Баришівському і Бородянському (високі показники коефіцієнта інсуляризованості - 0,52 та 0,42 при низькому відсотку заповідності - 0,4\% та 0,58\%) та Поліському районах. Для решти районів області характерні низькі показники рівня заповідності територій та середні коефіцієнта інсуляризованості (0,1-4,7\% та 0,31-0,36 відповідно).

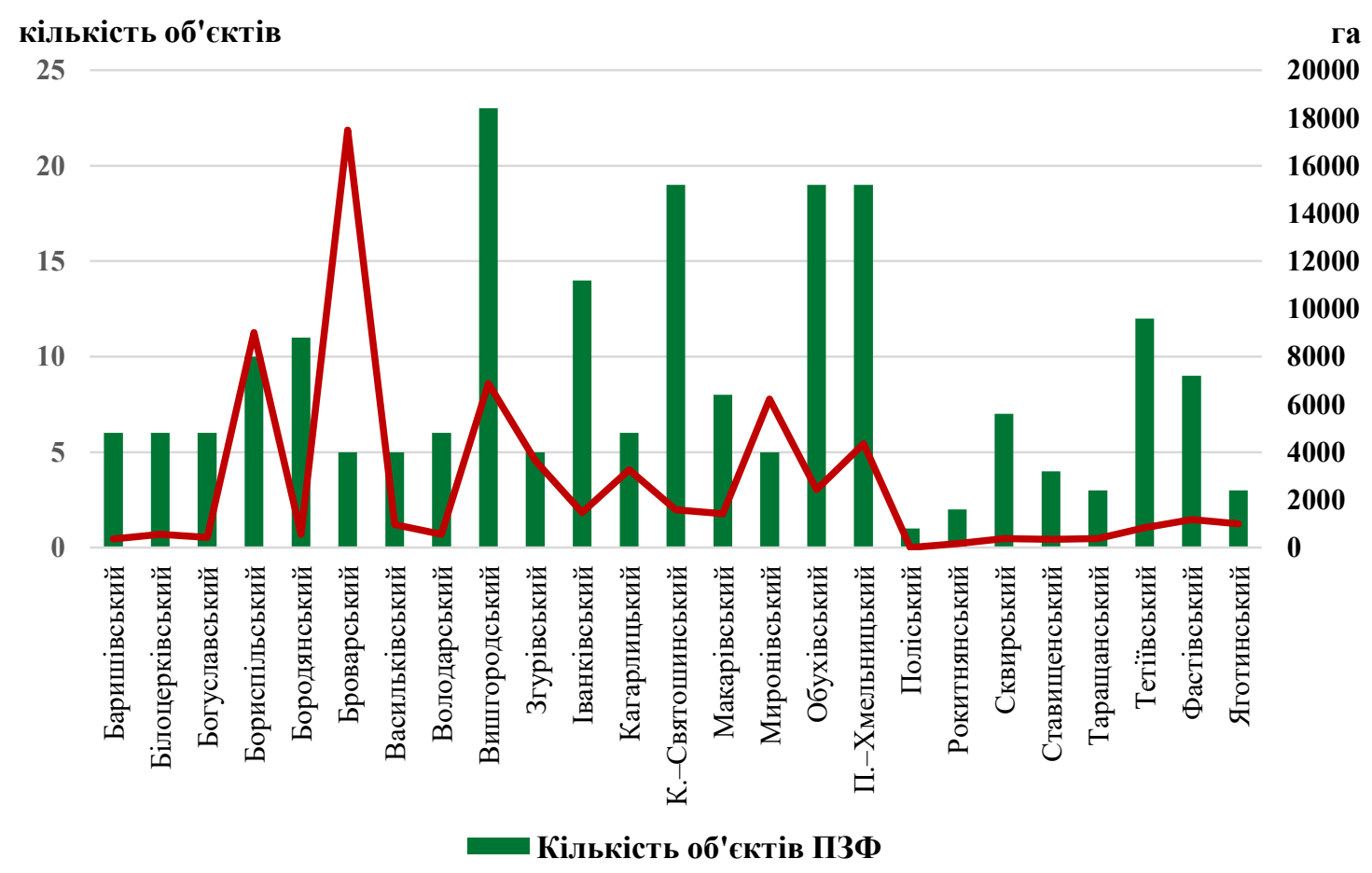

\section{Рис. 2. Регіональний розподіл об'сктів та площ ПЗФ Київської області}

Заповідні території перебувають у користуванні чотирьох основних землекористувачів. Так, лісові господарства $\epsilon$ землекористувачами 41,3 тис. га, 3 них 392,6 га перебувають у користуванні військового лісгоспу, 16,1 тис. га - у місцевих органів влади, 5,3 тис. га - агролісові підприємства, 2,2 тис. га - науково-дослідні установи. Іншими землекористувачами $є$ культурно-освітні заклади $(17,04$ га) і промислові підприємства $(18,5$ га). У зоні відчуження та безумовного відселення в 
Поліському та Іванівському районах основними землекористувачами земельних ділянок ПЗФ є Державне агентство України з управління зоною відчуження та Державне спеціалізоване виробниче комплексне підприємство «Чорнобильська Пуща» ${ }^{15}$.

Варто зазначити, що протягом 2010-2019 рр. відбулося зростання кількості об'єктів ПЗФ області та збільшення земельного фонду. Надалі це забезпечить раціональне використання біологічного i ландшафтного різноманіття, збереження цінних природних комплексів та екосистем, підтримання загального екологічного балансу регіону. Протягом вищезазначеного періоду було засновано понад 100 природоохоронних об’єктів, серед яких єдиний біосферний заповідник «Чорнобильський радіаційно-екологічний», регіональні ландшафтні парки «Пташиний рай», «Яготинський імені Гетьмана Кирила Розумовського», заказники «Чернечий ліс», «Хоцівський», «Сині дубки», «Стовп'язькі краєвиди» та інші, а площа земель ПЗФ збільшилась у понад 10 разів. Відповідно до Регіональної програми розвитку природно-заповідного фонду Київської області «Київщина заповідна» на 2017-2020 рр. в регіоні планувалося створення додаткових територій і об'єктів ПЗФ, які мають збільшити його площу до 443 тис. га. Це дасть змогу досягти показника 15,7\% від загальної площі області, визначеного Державною Стратегією регіонального розвитку України на період до 2020 року. Серед запроектованих об’єктів - національні природні парки (НПП) «Подесіння» (20 тис. га в межах Київської області), «Дівички» (38 тис. га), «Приірпіння - Чернечий ліс» (17,9 тис. га). Крім того, Департамент екології та природних ресурсів Київської обласної державної адміністрації проводить роботу зі створення природоохоронних об'єктів місцевого значення, а саме: ботанічних заказників «Михайлівсько-Рубежівський» $(105,7$ га), «Дмитрівський» (142,1 га), «Шандрівський ліс» (40 га), «Сеньківський» (424 га), «Личанський ліс» $(0,5$ га), «Миронівський» $(19,6$ га), ландшафтних заказників «Миньківський» $(76,9)$, «Руда долина» $(6,1$ га), «Чорний ліс» (27,2 га), «Чабанівський» (13,2 га), «Петрушківський ліс» (52,3 га), гідрологічного заказника «Неграш-Музичі» (34,9 га). Загалом у регіоні можна виділити 89 цінних природних територій та об'єктів, перспективних для заповідання, загальною площею 191,3 тис. га, з них 4 об'єкти загальнодержавного значення (вищезгадані НПП і регіональний ландшафтний парк «Надстугнянський») та 85 місцевого значення загальною площею 122,3 тис. га та 69 тис. га відповідно ${ }^{16}$.

Варто зазначити, що паралельно з розширенням природно-заповідної мережі в області спостерігається тенденція до збільшення кількості

\footnotetext{
${ }^{15}$ Екологічний паспорт Київської області. 2018 p. URL: https://menr.gov.ua/news/33529.html

16 Регіональна програма розвитку природно-заповідного фонду Київської області «Київщина заповідна» на 2017-2020 роки. URL: https://onedrive.live.com/view.aspx?resid=B61A3D3116EC0 9A7!143\&ithint=file\% 2cdocx\&authkey=!AKPkHIM3WudYDss
} 
приватних зоопарків, ландшафтних парків, які водночас із провідною туристсько-рекреаційною функцією виконують певною мірою i соціально-гуманітарну, екоосвітню, естетичну, природоохоронну та сприяють урізноманітненню рослинного, тваринного генофонду регіону. Серед них можна виділити Зоопарк XII місяців (с. Демидів, Вишгородський район), біопарк «Золотий фазан» (с. Вишківське, Ставищенський район), природний парк «Острів сакури» (смт. Володарка), дендропарк «Добропарк» (с. Мотижин, Макарівський район).

Одним із принципів формування мережі об'єктів ПЗФ є іiі ландшафтна репрезентативність, естетичні якості території. На естетичну цінність впливає різноманіття біотопів, ландшафтів, контрастність їх зміни, наявність на одній території озер, лісів, лук, річок, ярів у сукупності 3 мальовничими пейзажами тощо ${ }^{17}$. Рельєф Київської області рівнинний із загальним похилом до долини Дніпра. Північна частина області лежить у межах Поліської низовини. На сході в межах області - частина Придніпровської низовини. Найбільш підвищені й розчленовані південна та південно-західна частини зайняті Придніпровською височиною (висота 273 м над рівнем моря). Область розсічена вздовж потужною водною артерією - Дніпром, із двома великими водосховищами - Київським та Канівським. За типами зональних біотопів природно-заповідний фонд області (за межами зони відчуження) досить малий і незбалансований щодо розподілу територій, що охороняються. Переважна частина територій ПЗФ представлена дубовими, дубово-сосновими та дубовограбовими лісами. Незначною $є$ частка степових біотопів у складі наявних територій ПЗФ, із 226 об'єктів вони представлені лише в 20. Також недостатньо представлені і водно-болотні біотопи ${ }^{18}$.

Наявність об'єктів природно-заповідного фонду не лише сприяє підтриманню екологічної рівноваги в регіоні, а й формує потенціал для розвитку рекреаційної діяльності (рекреаційного природокористування). Території та об'єкти, що мають особливий природоохоронний статус, розглядаються нині як основний ресурс розвитку рекреаційної сфери за рахунок розширення спектра надання туристичних послуг та створення унікального турпродукту ${ }^{19}$.

Природно-заповідні об’єкти Київської області охоплюють території, які за особливостями своїх ландшафтів мають значний потенціал у використанні рекреаційною сферою регіону. Згідно 3 «Положенням про рекреаційну діяльність в межах територій та об’єктів природно-

\footnotetext{
17 Павленко Т.М. Оцінка естетичної привабливості території Полтавської області для цілей рекреації і туризму. Географія та туризм. 2010. Вип. 9. С. 95-99.

${ }_{18}$ Природно-заповідний фонд Київської області / Василюк О. та ін. Київ : НЕЦУ, 2012. 338 с.

19 Мельнійчук М.М., Безсмертюк Т.П. Природно-заповідний фонд у структурі рекреаційного природокористування Волинської області. URL: http://scinotesgeo.at.ua/Volume_6/Melnyichuk_ Bezsm.pdf
} 
заповідного фонду України» (Наказ Міністерства охорони навколишнього природного середовища України № 330 від 22 червня 2009 р.) основними напрямами ведення рекреаційної діяльності у межах територій та об’єктів ПЗФ є «створення умов для організованого та ефективного туризму, відпочинку та інших видів рекреаційної діяльності в природних умовах із додержанням режиму охорони заповідних природних комплексів та об'єктів; забезпечення попиту рекреантів на загальнооздоровчий, культурно-пізнавальний відпочинок, туризм, любительське та спортивне рибальство, полювання тощо; обгрунтування і встановлення допустимих антропогенних (рекреаційних) навантажень на території та об'єкти ПЗФ України; організація рекламно-видавничої та інформаційної діяльності, екологічної просвіти серед відпочиваючих, туристів у межах територій та об'єктів ПЗФ України; формування у рекреантів та місцевих жителів екологічної культури, бережливого та гуманного ставлення до національного природного надбання» ${ }^{20}$.

До установ ПЗФ України, які організовують і здійснюють рекреаційну діяльність, належать національні природні парки, біосферні заповідники, регіональні ландшафтні парки, парки-пам'ятки садово-паркового мистецтва, ботанічні сади, дендропарки. У Київській області вагоме загальнооздоровче та пізнавальне значення в рекреаційних цілях мають також заказники. Рекреаційно-туристична діяльність у межах цих територій та об'єктів може здійснюватися за такими основними видами, як утилітарний відпочинок, екскурсійна діяльність, туристична діяльність, оздоровлення, тихе рибальство та полювання.

Щорічно природно-заповідні об'єкти області відвідує близько 200 тис. осіб. Найбільшим попитом серед туристів користуються такі об'єкти ПЗФ, як НПП «Залісся», який містить набір ресурсів для задоволення рекреаційних потреб людей у культурно-пізнавальному відпочинку, орнітологічному, кінному, утилітарному туризмі, сафарі (фотосафарі), дендропарк «Олександрія», регіональні ландшафтні парки «Богуславль», «Трахтемирів», Ржищівський заказник загальнодержавного значення, ландшафтні заказники «Стайківські обрії», «Бориспільські острови», які включені як топові локації до програм турів вихідного дня. В області функціонують туристичні маршрути, в програми яких включені об'єкти та території ПЗФ. Серед них варто виділити такі: «Олені «Залісся» або «Місиями изарського полювання» (НПП «Залісся»); «Райські сади Київщини» (дендропарк «Олександрія», м. Біла Церква) - ландшафтний комплекс Буки (с. Буки Сквирського району Київської області); «Голлівуд над Дніпром: Трахтемирів та озеро Бучак» (с. Пії -

\footnotetext{
${ }^{20}$ Про затвердження Положення про рекреаційну діяльність у межах територій та об'єктів природно-заповідного фонду України : Наказ М-ва охорони навколишнього природного середовища України від 22 червня 2009 р. № 330. URL: https://zakon.rada.gov.ua/laws/show/z0679-09\#Text 
Трахтемирів: Державний історико-культурний заповідник «Трахтемирів» і Регіональний ландшафтний парк «Трахтемирів» - с. Бучак); «Трипілля та затоплена церква під Ржищевом» (м. Обухів - м. Трипілля с. Витачів - м. Ржищів - с. Балико-Щучинка - с. Уляники); «Змієві вали ma Васильківські Карпати» (с. Круглик - с. Здорівка - м. Васильків с. Велика Бугаївка - с. Ходосівка); «Романтичний Богуслав і містична Toтоха» (м. Богуслав - м. Кагарлик - м. Медвин - гора Тотоха м. Київ) ${ }^{21}$; «Переяслав-Хмельницький - Канів - Богуславські купелі» (м. Переяслав-Хмельницький - м. Канів - м. Богуслав (екскурсія регіональним ландшафтним парком «Богуславль», відвідування геологічної пам'ятки природи «Відслонення богуславських гранітів»), «Романтична Київщина» - дендропарк «Олександрія» (м. Біла Церква) ландшафтний комплекс Буки (с. Буки Сквирського p-ну Київської області) - с. Ковалівка (Васильківський р-н Київської області), «Трипільська казка» (м. Трипілля - с. Витачів - м. Біла Церква (дендропарк «Олександрія) ${ }^{22}$. Переважно споживачами такого туристичного продукту є кияни та жителі міст-супутників Києва.

У структурі надання туристичних послуг в межах територій і об'єктів природно-заповідного фонду Київщини переважає екскурсійна діяльність. Проте їх природно-рекреаційний потенціал має всі можливості для розвитку науково-пізнавального (екологічні стежки в НПП «Залісся», НПП «Білоозерський», орнітологічного (заказники «Пірнове» i «Жорнівський», «Журавлиний», «Дніпровсько-Деснянський», «Дніпровсько-Тетерівський», «Зачарована Десна», «Стайківські обрії»), водного, спортивно-оздоровчого та утилітарного туризму за умови дотримання природоохоронної складової.

Значний потенціал для розвитку туристичної галузі регіону в перспективі мають найбільш репрезентативні запроектовані об’єкти ПЗФ області загальнодержавного значення - національні природні парки «Дівички», «Приірпіння-Чернечий ліс», «Подесіння» та регіональний ландшафтний парк - «Надстугнянський». Естетична привабливість територій є сприятливою для відпочинку туристів та місцевих жителів. Так, на території запроектованого НПП «Дівички» в районі села Витачів вже функціонує малооблаштований оглядовий майданчик, 3 якого відкривається красива панорама на акваторію та острівний архіпелаг правого берега Канівського водосховища. У межах запроектованих об'єктів можна проводити оздоровчу (прогулянки, екскурсії, спортивні ігри, купання та інше), спортивну (туризм, рибальство), пізнавальнонатуралістичну (вивчення видового складу флори, фауни, спостереження

\footnotetext{
${ }^{21}$ НавколоUA: вебсайт. URL:http://www.navkoloua.com/tours-ukraine/day-tours/

${ }^{22}$ Етносвіт: вебсайт. URL: https://etnosvit.com/uk/ukraine/kyiv.html
} 
за скупченнями мігруючих птахів) рекреаційну діяльність, для проведення якої цінними є мало змінені природні комплекси ${ }^{23}$.

Таким чином, залучення об'єктів природно-заповідного фонду для рекреації та туризму $є$ цілком реальним та перспективним за умови створення і функціонування рекреаційної інфраструктури на визначених згідно із законодавством територіях та об'єктах ПЗФ, організації та інфраструктурного облаштування туристичних та екскурсійних маршрутів, еколого-освітніх стежок із дотриманням режиму охорони природних комплексів та об'єктів, координації діяльності установами ПЗФ суб’єктів рекреаційної діяльності незалежно від форми власності та підпорядкування 3 огляду на використання природних та історикокультурних ресурсів у межах територій та об’єктів ПЗФ, створення і ведення інформаційного банку даних щодо рекреаційних закладів, які розташовані в межах територій та об'єктів ПЗФ ${ }^{24}$.

Проте актуальним питанням розвитку рекреаційних послуг на природнозаповідних територіях залишається подальше вивчення місцевих природних ресурсів, організація менеджменту щодо їх збереження, еколого-освітнього i рекреаційного використання, модернізація туристичної інфраструктури, збільшення кількості робочих місць місцевих мешканців у рекреаційній сфері, забезпечення належного фінансування ${ }^{25}$.

Рекреаційна діяльність на території об'єктів ПЗФ Київської області виконує три важливих функції: соціальна - сприяє задоволенню потреб населення у відпочинку, оздоровленні, спілкуванні 3 природою, які особливо зросли в умовах пандемії Covid-19; економічна - забезпечує множину важливих екосистемних послуг, серед яких розвиток соціальної і виробничої інфраструктури на територіях рекреаційного природокористування, створення робочих місць, розширення сфери застосування праці, залучення інвестицій, як результат економічного забезпечення природно-заповідних територій та об'єктів, підвищення життєвого рівня населення регіону; природоохоронна - регулює стихійні потоки рекреантів, зменшує антропогенне навантаження на природні заповідні комплекси та забезпечує оптимальне поєднання рекреації 3 природоохоронною діяльністю.

\section{2. Проблеми та перспективи розвитку заповідної справи в Київській області}

Незважаючи на тривалу історію формування сучасної мережі ПЗФ Київської області, iї розвиток триває, а функціювання заповідних територій

\footnotetext{
${ }^{23}$ Проектований національний природний парк «Дівички» у Київській області. Серія: Збережемо українські степи. Київ : НЕЦУ, 2012. 44 с.

24 Про затвердження Положення про рекреаційну діяльність у межах територій та об'єктів природно-заповідного фонду України : Наказ М-ва охорони навколишнього природного середовища України від 22 червня 2009 р. № 330. URL: https://zakon.rada.gov.ua/laws/show/z0679-09\#Text

25 Мельнійчук М.М., Безсмертюк Т.П. Природно-заповідний фонд у структурі рекреаційного природокористування Волинської області. URL: http://scinotesgeo.at.ua/Volume_6/Melnyichuk_Bezsm.pdf 
зіштовхується 3 багатьма проблемами, які зумовлені як загальними причинами - законодавчими, інституційними, організаційними, фінансовими, так і місцевими - недбалістю місцевих владних структур, порушенням чинного законодавства, приватними інтересами бізнесу та місцевих жителів тощо ${ }^{26}$.

Однією з ключових сучасних проблем у заповідній справі України $\epsilon$ відсутність закріплених на місцевості меж об'єктів ПЗФ та незавершене винесення їх у натуру попри наявність відповідних рішень Президента України та профільного комітету Верховної Ради України. Насамперед це пов'язано з неповним фінансуванням розробки відповідних проектів землеустрою, а межі територій ПЗФ встановлюються лише після виділення коштів на винесення їх у натуру, тобто після створення територій ПЗФ, а не на етапі формування. Не проведено остаточних розмежувань земель державної і комунальної власності, що породжує конфлікти між сільськими радами, районними адміністраціями, новоствореними об'єднаними територіальними громадами щодо встановлення приналежності меж об'єктів ПЗФ до їх територій, регулювання лімітів ведення господарської діяльності на природнозаповідних територіях, їх фінансування ${ }^{27}$. Все це гальмує внесення інформації про території ПЗФ до державного земельного кадастру (ДЗК) і при винесенні їх меж у натуру фактично виносяться не межі, які існували під час їх створення, а новий варіант, який може відрізнятися внаслідок відчуження частини території ПЗФ для інших потреб до моменту їх встановлення. Наприклад, створений у 2012 р. ландшафтний заказник «Юрівський» фактично розташований на ділянці, що розміщена навпроти запланованої, а межі внесеного в натуру ландшафтного заказника «Пірнівський» відрізняються від зазначених під час проектування внаслідок появи приватних житлових забудов ${ }^{28}$.

Станом на 01.01.2019 р. в Київській області повністю визначені та винесені в натуру лише 56 об'єктів площею 25,8 тис. га, а частина територій взагалі не мають відповідних охоронних знаків i інформаційних аншлагів. Низькі темпи встановлення в натурі меж територій та об'єктів ПЗФ загрожують цілісності заповідних територій ${ }^{29}$.

На території низки об’єктів ПЗФ ведеться господарська діяльність, іноді самовільна і несумісна з цілями та режимом цих об'єктів, оскільки відсутні детальні вказівки про іiі обмеження на територіях ПЗФ у земельній документації і в умовах використання земельних ділянок у

\footnotetext{
${ }^{26}$ Природно-заповідний фонд Київської області / Василюк О. та ін. Київ : НЕЦУ, 2012. 338 с.

${ }^{27}$ Компанієць О.О., Лебедєва Н.І., Петриченко В.В., Компанієць А.В. Природно-заповідний фонд Запорізької області: сучасний стан, проблеми, перспективи розвитку. URL: http://sites.znu.edu.ua/bioeco-chem-sci/issues/files/2011/06/24/6611_1308413142_11kooppr.pdf

${ }^{28}$ Екологічний паспорт Київської області. 2018 p. URL: https://menr.gov.ua/news/33529.html

${ }^{29}$ Екологічний паспорт Київської області. 2018 p. URL: https://menr.gov.ua/news/33529.html
} 
складі актів на постійне користування земельними ділянками: розробка корисних копалин (піщаний кар'єр на території заказника «Тулинецькі переліски»), використання територій ПЗФ як полігонів для змагань на високопрохідних видах автотранспорту (заказник «Васильківські Карпати»), встановлення меморіальних i культових споруд на популяціях рідкісних рослин (заказник «Копачівські схили»), браконьєрство. Серйозною проблемою залишається ведення лісового господарства в межах ПЗФ, яке мало чим відрізняється від звичайних територій лісогосподарських підприємств. Адже спостерігається надмірне застосування лісовідновних та суцільних рубок, які дозволяються проводити підприємствам лісової галузі законодавством. Такі рубки спостерігались у природних заказниках - «Цезарівський», «Обухівський», «Дзвінківський», «Катюжанський», «Жуків Хутір» ${ }^{30}$. Це нівелює головне завдання заказника - збереження лісу.

Негативні тенденції посилюються i тим, що в Україні не відпрацьований економічний механізм, який здатний вирішувати проблеми та завдання збереження цінних заповідних територій та об'єктів в інтересах еколого орієнтованого та соціально-економічного розвитку $^{31}$. Фінансування установ ПЗФ є недостатнім. Території та об'єкти ПЗФ, що не мають адміністрацій, взагалі не отримують цільового державного фінансування. Тому реалії економічного сьогодення зумовлюють необхідність залучення природно-заповідних територій у сферу ринкових товарно-грошових відносин, формування маркетингової стратегії їх розвитку. Кожна адміністрація природнозаповідних територій має самостійно вести пошук нових фінансових джерел, розробляти бізнес-план діяльності. Комерціалізація заповідної справи, а саме поступове перетворення об'єктів ПЗФ у бізнес-установи, які мають заробляти кошти у зв'язку з недостатнім фінансуванням, негативно позначається на виконанні їхніх основних функцій у природоохоронній діяльності.

Однією 3 проблем щодо розвитку природно-заповідної мережі $є$ складна процедура отримання погоджень на створення нових природоохоронних територій, яку досить легко саботувати навіть за наявності всіх відповідних документів та невиконання рішень щодо забезпечення належного функціонування вже створених природоохоронних територій. Наприклад не виконаний у повному обсязі Указ Президента України від 1 грудня 2008 р. № 1129/208 «Про розширення мережі та територій національних природних парків та інших природнозаповідних об'єктів» щодо створення НПП «Подесіння», «Дніпровсько-

\footnotetext{
${ }^{30}$ Екологічний паспорт Київської області. 2018 p. URL: https://menr.gov.ua/news/33529.html

31 Воробйова О.А. Природно-заповідні території в складі екологічної інфраструктури: роль, функціï, вектори розвитку. URL: http://dspace.nbuv.gov.ua/bitstream/handle/123456789/67165/06Vorobiova.pdf?sequence $=1$
} 
Тетерівський» ${ }^{32}$. Створені у 2009 р. НПП «Білоозерський» (Указ Президента України № 1048/2009 від 11 грудня 2009 p. $^{33}$ ) та «Залісся» (№ 1049/2009 від 11 грудня 2009 p. $^{34}$ ) продовжують використовуватися як мисливських резиденцій, на територіях яких здійснюються полювання і рубки лісу ${ }^{35}$.

Найбільш типовими в практичному плані проблемами ПЗФ області є:

- відсутність механізмів економічного стимулювання для створення нових об'єктів ПЗФ та відшкодування збитків землекористувачам, викупу земельних ділянок для заповідання;

- недостатня якість земельної кадастрової документації;

- недостатне фінансування на місцевому та державному рівні заходів щодо розширення мережі територій та об'єктів;

- саботування відповідними органами та організаціями процесу створення об'єктів ПЗФ навіть за наявності всіх відповідних документів та не виконання рішень щодо забезпечення належного функціонування вже створених природоохоронних територій;

- недосконалість законодавчої бази, що неповністю регулює процеси самозахоплення, приватизація земель ПЗФ, які свого часу були надані як службові земельні наділи, розпаювання, надання їх для потреб, несумісних із виконанням природоохоронних функцій, серед яких будівництво індивідуальних житлових будинків, комплексів;

- невідповідність сучасним вимогам стану моніторингу природних комплексів на територіях ПЗФ із метою виявлення перспективних для заповідання територій та збереження наявних, у зв'язку з фінансовою незабезпеченістю;

- недостатній рівень забезпеченості природно-заповідної сфери кваліфікованими кадрами;

- недостатня екологічна свідомість i необізнаність громадян, представників органів державної влади та місцевого самоврядування із потенціалом ПЗФ регіону, необхідністю його збереження ${ }^{36}$.

3 метою вирішення проблем, які перешкоджають стабільному та ефективному розвитку територій та об’єктів ПЗФ у Київській області, необхідно забезпечити на практиці реалізацію комплексу таких заходів:

\footnotetext{
32 Про розширення мережі та територій національних природних парків та інших природнозаповідних об’єктів : Закон України від 1 грудня 2008 р. № 1129/208. URL: https://zakon.rada.gov.ua/ laws/show/1129/2008\#Text

${ }^{33}$ Про створення національного природного парку «Білоозерський» : Указ президента України від 11 грудня 2009 р. № 1048/2009. URL: https://zakon.rada.gov.ua/laws/show/1048/2009\#Text t

34 Про створення національного природного парку «Залісся»: Указ президента України від 11 грудня 2009 р. № 1049/2009. URL: https://zakon.rada.gov.ua/laws/show/1049/2009\#Text

${ }^{35}$ Протокол № 6 засідання громадської ради при Міністерстві енергетики та захисту довкілля України. URL: https://menr.gov.ua/files/docs/hromadska_rada/2019/PROTOKOL_6\%20\%D0\%B2\%D1\% 96\%D0\%B4\%2031.10.2019.pdf

${ }^{36}$ Компанієць О.О., Лебедєва Н.І., Петриченко В.В., Компанієць А.В. Природно-заповідний фонд Запорізької області: сучасний стан, проблеми, перспективи розвитку. URL: http://sites.znu.edu.ua/bioeco-chem-sci/issues/files/2011/06/24/6611_1308413142_11kooppr.pdf
} 
- узгодити земельне, лісове, природоохоронне законодавство та законодавство про місцеве самоврядування в частині заповідної справи;

- створити науково обгрунтовану мережу територій та об'єктів ПЗФ як органічну складову частину сталого розвитку держави та підвищити іiі репрезентативність;

- провести інвентаризацію земель ПЗФ області, їх реального якісного та кількісного стану;

- здійснити еколого-економічну оцінку об’єктів ПЗФ із метою визначення їх фактичної вартості ${ }^{37}$;

- забезпечити розробку i проведення фундаментальних та прикладних наукових досліджень у сфері заповідної справи та регулярний моніторинг стану екосистем ПЗФ;

- посилити систему державного контролю у сфері дотримання вимог режиму територій та об'єктів ПЗФ;

- встановити мораторій на зміну цільового призначення земель природоохоронного призначення, розширення меж населених пунктів шляхом включення до них перспективних для заповідання та наявних заповідних об'єктів;

- створити на базі територій та об’єктів ПЗФ системи збалансованого природокористування, еколого-освітнього та рекреаційного використання їх ресурсів ${ }^{38}$.

Одним із перспективних напрямів розвитку ПЗФ регіону є участь у міжнародному співробітництві у сфері заповідної справи та використання зарубіжного досвіду для іï розбудови. Питання охорони природного довкілля варто розглядати як один із пріоритетних напрямів євроатлантичної інтеграції України. Створення природоохоронних територій у Київській області передбачено низкою нижченаведених чинних міжнародних конвенцій і програм в Україні.

1. Смарагдова мережа Свропи (the Emerald Network) має на меті поєднати територіï особливого природоохоронного значення (Areas of Special Conservation Interest) - місця існування рідкісних тварин та оселищ у країнах, які не є членами Свропейського Союзу та виробити загальноєвропейський підхід до охорони природних середовищ ${ }^{39}$. У 2019 р. перелік українських територій, які офіційно отримали статус територій Мережі Емеральд (Смарагдова мережа), включав 377 одиниць, 3 яких 15 розміщено в межах Київської області, що становить близько

\footnotetext{
${ }^{37}$ Щербак К.О. Просторово-екологічні аспекти досліджень структурних елементів природнозаповідного фонду Київської області. Землеустрій, кадастр і моніторинг земель. 2013. № 3. С. 53-60. URL: http://nbuv.gov.ua/UJRN/Zemleustriy_2013_3_10.

${ }^{38}$ Компанієць O.О., Лебедєва Н.І., Петриченко В.В., Компанієць А.В. Природно-заповідний фонд Запорізької області: сучасний стан, проблеми, перспективи розвитку. URL: http://sites.znu.edu.ua/bioeco-chem-sci/issues/files/2011/06/24/6611_1308413142_11kooppr.pdf

${ }_{39}$ Смарагдова мережа Донецької області / Василюк О.В. та ін. Харків : ПРАТ «Харківська книжкова фабрика «Глобус», 2018. 104 с.
} 
$20 \%$ площі регіону ${ }^{40}$. Регіон дослідження входить у трійку лідерів за обсягом площі смарагдових об’єктів. До складу цієї мережі області входять 2 запроектовані національні природні парки загальнодержавного значення, 1 біосферний заповідник та регіональний ландшафтний парк, 2 території (Київське Подесіння та Нижнє Подесіння), що становлять основу заповідного ядра запроектованого національного парку «Подесіння» (табл. 2).

Таблиця 2

\section{Затверджені та проектовані території}

Смарагдової мережі у Київській області ${ }^{41}$

\begin{tabular}{|c|c|c|c|c|c|}
\hline $\begin{array}{l}\text { № } \\
\text { п/II }\end{array}$ & Код території & $\begin{array}{c}\text { Назва в ресстрі } \\
\text { територій } \\
\text { Смарагдової мережі }\end{array}$ & Назва українською & Площа (га) & $\begin{array}{c}\text { Кількість } \\
\text { типів } \\
\text { оселищ* }\end{array}$ \\
\hline 1. & UA0000046 & $\begin{array}{l}\text { Chornobylskyi Biosphere } \\
\text { Reserve }\end{array}$ & $\begin{array}{l}\text { Чорнобильський } \\
\text { радіаційно-екологічний } \\
\text { біосферний заповідник }\end{array}$ & 227381,0 & 25 \\
\hline 2. & UA0000047 & $\begin{array}{l}\text { Mizhrichynskyi Regional } \\
\text { Landscape Park }\end{array}$ & $\begin{array}{l}\text { Межріченський } \\
\text { регіональний } \\
\text { ландшафтний парк }\end{array}$ & 102434,0 & 25 \\
\hline 3. & UA0000094 & Kyivske Reservoir & Київське водосховище & 54422,0 & 13 \\
\hline 4. & UA0000111 & Kanivske Reservoir & Канівське водосховище & 67264,0 & 20 \\
\hline 5. & UA0000161 & Unava & Унава & 13331,0 & 7 \\
\hline 6. & UA0000175 & Ponyzia Stuhny & Пониззя Стугни & 6830,0 & 10 \\
\hline 7. & UA0000233 & Kyivske Podesennia & Київське Подесіння & 20621,0 & 23 \\
\hline 8. & UA0000237 & Zaplava Supoiu & Заплава Супій & 8807,0 & 11 \\
\hline 9. & UA0000272 & Ros river valley & Долина річки Рось & 90800,1 & 24 \\
\hline 10. & UA0000302 & Supiy river valley & Долина річки Супій & 20490,9 & \\
\hline 11. & UA0000320 & Teteriv river valley & Долина річки Тетерів & 51710,3 & \\
\hline 12. & UA0000337 & Divychky & $\begin{array}{l}\text { Запроектований } \\
\text { національний природний } \\
\text { парк «Дівички» }\end{array}$ & 19036.47 & \\
\hline 13. & UA0000338 & $\begin{array}{l}\text { Pryirpinnya and } \\
\text { Chernechyi Forest }\end{array}$ & $\begin{array}{l}\text { Запроектований } \\
\text { національний природний } \\
\text { парк «Приірпіння та } \\
\text { Чернечий ліс» }\end{array}$ & 6094,7 & \\
\hline 14. & UA0000342 & Irpin river valley & Долина річки Ірпінь & 15039,0 & \\
\hline 15. & UA0000351 & Tulyntsi - Makedony & Тулинці - Македони & 832,6 & 3 \\
\hline
\end{tabular}

*- оселища, що перебувають під загрозою зникнення, потребують спеціальних заходів для їх збереження та мають особливу міжнародну цінність

Значна частка територій Смарагдової мережі Київщини створена на основі заповідних об'єктів області або включає землі, які мають природоохоронний статус: UA0000175 Пониззя Стугни включає гідрологічні заказники місцевого значення «Урочище «Гощів»,

\footnotetext{
${ }^{40}$ Updated list of officially adopted Emerald sites (December 2019). URL: https://rm.coe.int/updated-listof-officially-adopted-emerald-sites-december-2019-/168098ef51

${ }^{41}$ Інтерактивний картографічний вебзастосунок «Смарагдова мережа України: база даних Species of Resolution 6. Database». URL: http://carto-lab.maps.arcgis.com/apps/webappviewer/index.html? id $=4 \mathrm{e} 00799196344 \mathrm{c} 9 \mathrm{c} 8 \mathrm{ae} 624 \mathrm{aa} 507570 \mathrm{f0}$
} 
«Копачівський», ландшафтні заказники місцевого значення «Копачівські схили», UA0000161 Унава - територію лісового заказника «Урочище «Унава», парка-пам'ятки садово-паркового мистецтва «Фастівський», UA0000233 Київське Подесіння - загальнозоологічний «Урочище «Бобровня» та орнітологічний «Пернівський», заказники місцевого значення, UA0000237 Заплава Супій - гідрологічні заказники загальнодержавного («Усівський») та місцевого значення («Болото Супій») $)^{42}$.

Серед потенційних об'єктів для отримання статусу Сайтів Мережі Емеральд (Смарагдова мережа) на основі наукових даних у Київській області дослідники виділяють територію UA0000566 Ржищівські балки ${ }^{43}$. Для України створення цієї мережі є важливим завданням не лише в контексті посилення природоохоронної діяльності, а й євроінтеграційного процесу.

2. Рамсарська конвенція або "Конвениія з водно-болотних угідь міжнародного значення як середовища перебування водоплавних птахів». Перспективними водно-болотними угіддями для визнання Рамсарською конвенцією в Київській області визначено водно-болотне угіддя «Ділянка між Києвом та Українкою» площею 25 тис. га, що входить до складу найбільшого за площею в Україні проектованого національного природного парку «Дівички». У межах водно-болотного угіддя також розташовані ландшафтний заказник загальнодержавного значення «Козинський» (967 га), ландшафтний заказник місцевого значення «Жуків острів» (361 га), загальнозоологічний заказник місцевого значення «Острови Ольжин та Козачий» (470 га), ландшафтний заказник місцевого значення «Заказник на лівому березі оз. Конча» (80 га), іхтіологічний заказник місцевого значення «Процівський» $(563 \text { га) })^{44}$.

3. Дочірні угоди Бонської конвениії, серед яких Угоди про збереження популячій європейських видів кажанів (EUROBATS) та збереження афро-свразійських мігруючих водно-болотних птахів (AEWA). На Київщині ключовими місцями для збереження кажанів $\epsilon$ Чорнобильський радіаційно-екологічний біосферний заповідник, де виявлено 9 видів червонокнижних видів рукокрилих, лісовий заказник місцевого значення «Гореницький». Значним кроком у реалізації вимог цієї конвенції $є$ створення НПП «Приірпіння та Чернечий ліс» та «Дівички», де розташований Дніпровський екологічний коридор - місце перепочинку мігруючих водно-болотних птахів.

\footnotetext{
42 Інтерактивний картографічний вебзастосунок «Смарагдова мережа України: база даних Species of Resolution 6. Database». URL: http://carto-lab.maps.arcgis.com/apps/webappviewer/ index.html?id=4e00799196344c9c 8ae624aa507570f0

43 Інтерактивний картографічний вебзастосунок «Смарагдова мережа України: база даних Species of Resolution 6. Database». URL: http://carto-lab.maps.arcgis.com/apps/webappviewer/ index.html?id=4e00799196344c9c 8ae624aa507570f0

${ }^{44}$ Природно-заповідний фонд Київської області / Василюк О. та ін. Київ : НЕЦУ, 2012. 338 с. 
4. Свропейська ландшафтна конвенція, метою якої є «підтримка процесів охорони, регулювання та планування ландшафтів, а також організація європейської співпраці 3 питань ландшафту» ${ }^{45}$. Велику цінність для реалізації низки вихідних положень конвенції становлять ландшафти Чорнобильського радіаційно-екологічного біосферного заповідника, проектованого національного природного парку «Дівички» (особливо на правому березі Канівського водосховища), ландшафтних заказників «Дніпровсько-Деснянський», «Васильківські Карпати», «Зачарована Десна», Богуславського гранітного оголення.

5. IBA-програма (Important Bird Areas, 2001) - програма міжнародної організації із захисту птахів і збереження середовища їх існування BirdLife International з ідентифікації та моніторингу територій, які мають велике значення для збереження видового різноманіття і кількісного багатства птахів, сприяння їх інтеграції в національні природно-заповідні об'єкти ${ }^{46}$. У межах Київської області виділено 10 об'єктів загальною площею понад 320 тис. га, що включають 11 природоохоронних територій, серед яких заказники загальнодержавного значення «Чорнобильський спеціальний зоологічний», орнітологічний «Журавлиний», ландшафтний «Дніпровсько-Деснянський», гідрологічний «Усівський», місцевого значення - гідрологічний «Болото Супій», загальнозоологічний «Стайківські обрії», Чорнобильський радіаційноекологічний біосферний заповідник, акваторія проектованого НПП «Дівички». Притулком для мігруючих птахів, включених до міжнародних охоронних списків, $є$ ландшафтний заказник місцевого значення «Зачарована Десна» ${ }^{47}$.

6. Проект за підтримки Глобального екологічного фонду через Програму ООН із навколишнього середовища (ЮНЕП) «Збереження, посилення та управління запасами вуглецю та біорізноманіттям $у$ Чорнобильській зоні відчуження» (UNEP-GEF). Він є логічним продовженням основних положень програми ЮНЕСКО «Людина i Біосфера». «Метою проєкту UNEP-GEF є сприяння Україні у створенні системи природоохоронної діяльності в межах і навколо Чорнобильської зони відчуження для збереження цінних природних комплексів Полісся, які неможливо використовувати за традиційними господарськими напрямами, а також на підтримку природних процесів кругообігу вуглецю» ${ }^{48}$.

\footnotetext{
45 Фауна України: охоронні категорії. Довідник / О. Годлевська та ін. Вид. 2-ге, переробл. і допов. Київ, 2010. 80 с.

${ }^{46}$ Фауна України: охоронні категорії. Довідник / О. Годлевська та ін. Вид. 2-ге, переробл. і допов. Київ, 2010.80 с.

47 Українське товариство охорони птахів Українське товариство охорони птахів: вебсайт. http://birdlife.org.ua/index.php?PGID=859

48 Чорнобильський радіаційно-екологічний біосферний заповідник: вебсайт. URL: https://zapovidnyk.org.ua/ index.php?lang=uk\&fn=novp\&pid=2019-04-16-20-04-58-7371
} 
Перспективним та раціональним видом сталого використання природного потенціалу ПЗФ області $\epsilon$ регульована рекреаційна діяльність. Розвиток рекреаційного природокористування на основі природно-заповідних територій та об'єктів сприятиме вирішенню низки завдань: регулюванню стихійних потоків рекреантів, вдосконаленню туристичного іміджу області, залученню туристів, створенню нових робочих місць, екологічному вихованню населення, вдосконаленню інфраструктури та сфери послуг. Із метою сприяння розвитку рекреаційної та оздоровчої діяльності в межах об’єктів ПЗФ необхідно:

- оптимізувати рекреаційне використання територій та об'єктів ПЗФ, облаштувавши зони відпочинку, визначивши допустимі рекреаційні навантаження на природні комплекси в кожному конкретному випадку, можливі види рекреації та здійснювати систематичний контроль за дотриманням цих норм;

- сприяти розвитку спеціальних видів туризму, що завдають найменше шкоди біотопам (фотосафарі, орнітологічний та екологічний туризм);

- забезпечити реалізацію економічних проектів ПЗФ у сфері рекреації та інших видів господарської діяльності у формах, що не завдають шкоди природному середовищу;

- сприяти широкому залученню місцевого населення та громад до рекреаційної діяльності;

- удосконалити інформаційно-маркетингове забезпечення просування екоосвітніх та екотуристичних пропозицій ${ }^{49}$.

На нашу думку, для вирішення всіх зазначених положень, насамперед, необхідна нова природоохоронна державна політика та відповідне фінансове забезпечення реалізації всіх заходів.

\section{ВИСНОВКИ}

Розвиток природно-заповідного фонду України є одним з основних пріоритетів екологічної політики держави. Він має особливу природоохоронну, наукову, естетичну, рекреаційну цінність та сприяє збереженню природної різноманітності ландшафтів, генофонду тваринного і рослинного світу, підтриманню екологічної рівноваги території. На території Київської області розташовано 226 об’єктів природно-заповідного фонду загальною площею 344,46 тис. га, 3 них 25 об'єктів загальнодержавного і 201 об'єкт місцевого значення, загальною площею 308,74 тис. га та 35,72 тис. га відповідно. Заповідність має 12,2\% території області. Показник щільності об'єктів

\footnotetext{
49 Регіональна програма розвитку природно-заповідного фонду Київської області «Київщина заповідна» на 2017-2020 роки. URL: https://onedrive.live.com/view.aspx?resid=B61A3D3116EC09A7! 143\&ithint $=$ file $\% 2$ cdocx\&authkey=!AKPkHlM3WudYDss
} 
дослідження становить 0,80 об'єктів на 100 км$^{2}$. Коефіцієнт інсуляризованості сягає позначки 0,4 , що свідчить про наявність значної кількості природно-заповідних об’єктів площею менше 50 га (134 об’єкти ПЗФ), які є екологічно нестабільними та не виконують повною мірою своїх функцій. Природно-заповідний фонд області охоплює цінні території та окремі ділянки в контексті збереження їх у природному стані й біорізноманіття.

Наявність об'єктів природно-заповідного фонду має значний потенціал для розвитку рекреаційної сфери та проведення роботи з екологічної освіти та виховання населення регіону. Щорічно природно-заповідні об'єкти Київської області з метою задоволення рекреаційних потреб відвідує близько 200 тис. рекреантів. Рекреаційна діяльність на території об’єктів ПЗФ Київської області виконує 2 важливі функції: соціальну сприяє задоволенню потреб населення у відпочинку, оздоровленні, спілкуванню з природою; економічну - забезпечує розвиток соціальної і виробничої інфраструктури на територіях рекреаційного природокористування, сприяє створенню робочих місць, покращенню фінансового становища природно-заповідних територій та об'єктів.

Незважаючи на тривалий період становлення сучасної мережі ПЗФ Київської області, функціювання заповідних територій зіштовхується 3 проблемами законодавчого, інституційного, організаційного, фінансового характеру. Для їх вирішення необхідно забезпечити вирішення комплексу заходів щодо забезпечення належних умов для реалізації єдиної державної політики у сфері розвитку заповідної справи в Україні, створити науково обгрунтовану мережу територій та об'єктів ПЗФ та сформувати на ii основі екомережу як складник Пан-Свропейської екомережі, забезпечити розробку та здійснення наукових досліджень $\mathrm{i}$ моніторингу екосистем, створити на базі територій та об'єктів ПЗФ систему збалансованого природокористування, еколого-освітнього та рекреаційного використання їх ресурсів.

3 метою забезпечення раціонального використання та охорони об'єктів природно-заповідного фонду області розроблено Регіональну програму розвитку природно-заповідного фонду Київської області «Київщина заповідна» на 2017-2020 роки. Виконання iі концептуальних положень забезпечить збільшення площі природно-заповідного фонду, збереження генофонду рослинного i тваринного світу, сприятиме запобіганню використання територій та об'єктів ПЗФ не за цільовим призначенням, проведенню прикладних наукових досліджень у сфері заповідної справи, сталому природокористуванню в межах територій та об'єктів ПЗФ, поліпшенню фінансового забезпечення розвитку заповідної справи, підвищенню екологічної поінформованості населення. 


\section{АНОТАЦІЯ}

У статті відображено результати дослідження природно-заповідного фонду Київської області як структурного елементу екомережі та його територіальної і функціональної структури. Проаналізовано ефективність ПЗФ області 3 використанням коефіцієнта інсуляризованості та показника заповідності території. Визначено ландшафтно-географічну репрезентативність мережі заповідних територій. Розглянуто роль та значення природно-заповідних територій і об'єктів для розвитку рекреаційної галузі в регіоні. Означено найбільш відомі та використовувані в рекреаційній діяльності природоохоронні території та об'єкти. Визначено проблеми формування єдиної та науково обгрунтованої, репрезентативної системи заповідних об'єктів. Запропоновано заходи ефективного розвитку природно-заповідної справи Київської області.

\section{ЛІТЕРАТУРА}

1. Андронов В.А., Варивода Є.О., Тітенко Г.В. Заповідна справа : навч. посібник. Харків : НУЦЗУ, 2013. 204 с.

2. Воробйова О.А. Природно-заповідні території в складі екологічної інфраструктури: роль, функції, вектори розвитку. URL: http://dspace.nbuv.gov.ua/bitstream/handle/123456789/67165/06Vorobiova.pdf?sequence $=1$

3. Дуднікова I.I. Концепція заповідної справи: сутність, значення, основні тенденції становлення і формування. URL: http:/www.zgia.zp.ua/ gazeta/visnik_50_231.pdf

4. Екологічний паспорт Київської області. 2018 p. URL: https:// menr.gov.ua/news/33529.html

5. Етносвіт: вебсайт. URL: https://etnosvit.com/uk/ukraine/kyiv.html

6. Землі природно-заповідного фонду Київської області: сучасний стан, проблеми, перспективи. URL: http://journals.nubip.edu.ua/index.php/ Zemleustriy/article/viewFile/6539/6411

7. Інтерактивний картографічний вебзастосунок «Смарагдова мережа України: база даних - Species of Resolution 6. Database». URL: http://carto-lab.maps.arcgis.com/apps/webappviewer/index.html?id=4e00799 196344c9c8ae624aa507570f0

8. Касперевич Л.В. Аналіз стану природнојзаповідного фонду України та Львівської області. URL: http://www.investplan.com.ua/pdf/9_2017/ 17.pdf

9. Компанієць О.О., Лебедєва Н.І., Петриченко В.В., Компанієць А.В. Природно-заповідний фонд Запорізької області: сучасний стан, проблеми, перспективи розвитку. URL: http://sites.znu.edu.ua/bio-ecochem-sci/issues/files/2011/06/24/6611_1308413142_11kooppr.pdf 
10. Мельнійчук М.М., Безсмертюк Т.П. Природно-заповідний фонд у структурі рекреаційного природокористування Волинської області. URL: http://scinotesgeo.at.ua/Volume_6/Melnyichuk_Bezsm.pdf

11. НавколоUA_: вебсайт. URL: http://www.navkoloua.com/tours-ukraine/ day-tours/

12. Павленко Т.М. Оцінка естетичної привабливості території Полтавської області для цілей рекреації і туризму. Географія та туризм. 2010. Вип. 9. С. 95-99.

13. Природно-заповідний фонд Київської області / Василюк О. та ін. Київ : НЕЦУ, 2012. 338 с.

14. Про затвердження Положення про рекреаційну діяльність у межах територій та об'єктів природно-заповідного фонду України : Наказ М-ва охорони навколишнього природного середовища України від 22 червня 2009 p. № 330. URL: https://zakon.rada.gov.ua/laws/show/ z0679-09\#Text

15. Про природно-заповідний фонд України : Закон України від 16 червня 1992 p. № 2456-XII16. URL: https://zakon.rada.gov.ua/laws/ show/2456-12\#Text

16. Про розширення мережі та територій національних природних парків та інших природно-заповідних об’єктів : Указ Президента України від 1 грудня 2008 р. № 1129/2008. URL: https://zakon.rada.gov.ua/ laws/show/1129/2008\#Text

17. Про створення національного природного парку «Білоозерський» : Указ Президента України від 11 грудня 2009 р. № 1048/2009. URL: https://zakon.rada.gov.ua/laws/show/1048/2009\#Text t

18. Про створення національного природного парку «Залісся» : Указ Президента України від 11 грудня 2009 р. № 1049/2009. URL: https://zakon.rada.gov.ua/laws/show/1049/2009\#Text

19. Про створення Чорнобильського радіаційно-екологічного біосферного заповідника : Указ Президента України від 26 квітня 2016 р. № 174/2016 p. URL: https://zakon.rada.gov.ua/laws/show/174/2016\#Text

20. Проектований національний природний парк «Дівички» у Київській області. Серія: Збережемо українські степи. Київ : НЕЦУ, 2012. $44 \mathrm{c}$.

21. Протокол № 6 засідання громадської ради при Міністерстві енергетики та захисту довкілля України. URL: https://menr.gov.ua/files/ docs/hromadska_rada/2019/PROTOKOL_6\%20\%D0\%B2\%D1\%96\%D0\% B4\%2031.10.2019.pdf

22. Регіональна програма розвитку природно-заповідного фонду Київської області «Київщина заповідна» на 2017-2020 роки. URL: https://onedrive.live.com/view.aspx?resid=B61A3D3116EC09A7!143\&ithint $=$ file $\% 2$ cdocx\&authkey $=$ !AKPkHlM3WudYDss 
23. Смарагдова мережа Донецької області / Василюк О.В. та ін. Харків : ПРАТ «Харківська книжкова фабрика «Глобус», 2018. 104 с.

24. Українське товариство охорони птахів Українське товариство охорони птахів : вебсайт. http://birdlife.org.ua/index.php?PGID=859

25. Фауна України: охоронні категорії. Довідник / О. Годлевська та ін. Вид. 2-ге, переробл. і допов. Київ, 2010. 80 с.

26. Чорнобильський радіаційно-екологічний біосферний заповідник : вебсайт. URL: https://zapovidnyk.org.ua/index.php?lang=uk\&fn=novp\&pid= 2019-04-16-20-04-58-7371

27. Щербак К.О. Просторово-екологічні аспекти досліджень структурних елементів природно-заповідного фонду Київської області. Землеустрій, кадастр і моніторинг земель. 2013. № 3. C. 53-60. URL: http://nbuv.gov.ua/UJRN/Zemleustriy_2013_3_10

28. Updated list of officially adopted Emerald sites (December 2019). URL: $\quad$ https://rm.coe.int/updated-list-of-officially-adopted-emerald-sitesdecember-2019-/168098ef51

\section{Information about the authors: \\ Pologovska Yu. Yu.,}

Lecturer at the Department of Geography

National Pedagogical Dragomanov University

9, Pyrogova str. Kyiv, 01601, Ukraine

Shchabelska V. H.,

Candidate of Geographic Sciences (Ph. D.), Associate Professor,

Head of the Department of Geography

National Pedagogical Dragomanov University

9, Pyrogova str. Kyiv, 01601, Ukraine 